\title{
Lactose Intolerance and Colorectal Cancer
}

\author{
Jong-Woo Kim \\ Department of Surgery, CHA University School of Medicine, Seongnam, Korea
}

\section{See Article on Page 169-172}

Humans are born with initially high levels of lactase expression from intestine enterocytes. But lactase is gradually down-regulated after weaning of breast feeding and during growth which results in diminished lactase expression in almost two-thirds of the world's population except caucacian; This causes lactose intolerance. Studies of lactose intolerance have demonstrated that despite polymorphisms, little difference in lactase expression is seen in infants, but with aging, the mutations become increasingly relevant, with down-regulating mRNA transcripts of latase with causing decreased its expression with aging $[1,2]$.

Therfore, lactose intolerance appears after younger years, at which time lactase activity in the small intestine has become insufficient or is absent. The transit of the undigested and unabsorbed lactose to the colon is followed by extra bacterial fermentation and production of gas and short chain fatty acids. In addition to their being materials that cause irritation, these compounds can greatly increase the luminal osmolality and interfere with water absorption in the colon, and therefore, cause substantial watery diarrhea with other symptoms as abdominal pain, bloating, flatulence, etc. [3-5].

Lactose intolerant adults normally restrict the amount of milk and dairy products in their diets, even though dairy foods are nutritious resources of lipids, protein, vitamins and minerals, particularly calcium. Dairy products might exert a protective or adverse effect in different physiological abnormalities because of differences in certain bioactive functions between lactose-intolerance and normal subjects $[6,7]$. Colorectal, ovarian and prostate cancers are the most common cancer types for which a protective or adverse effect of milk and dairy foods has been investigated and discussed for a long time [8-10].

Correspondence to: Jong-Woo Kim, M.D.

Department of Surgery, CHA Bundang Medical Center, CHA University, 59 Yatap-ro, Bundang-gu, Seongnam 13496, Korea

Tel: +82-31-780-5250, Fax: +82-31-780-5259, E-mail: kjw@cha.ac.kr

(C) 2017 The Korean Society of Coloproctology

This is an open-access article distributed under the terms of the Creative Commons Attribution NonCommercial License (http://creativecommons.org/licenses/by-nc/4.0) which permits unrestricted noncommercial use, distribution, and reproduction in any medium, provided the original work is properly cited.
Diet has a great effect on the incidence and progression of colorectal cancer. Some benficial components of dairy foods have been shown experimentally to have protective effects against colon cancer. These components include calcium and vitamin D, conjugated linoleic acid, sphingolipids, etc. Some short chain fatty acids such as butyric acid, which are important for the epithelial stability, are formed through the milk products fermentated by colonic lactobacilli. These beneficial normal flora, lactobacilli and bifidus bacilli are also increased with the consumption of dairy foods. Calcium and vitamin D regulate cell growth and promote cell differentiation by stimulating calcium-sensing receptors, and calcium itself forms nontoxic insoluble compounds by binding with vulnerable free fatty acid and free bile acids $[11,12]$.

Studies in Hungarian and Finnish populations have shown an increased risk for colorectal cancer among polymorphism of lactase nonpersistent subjects. However, other studies on Italian, British and Spanish populations do not support such an association. I would like to refer to the ethnic difference between these 2 population groups: the Hungarian, Finnish population group and the Italian, British, Spanish population group. The members of the population in the first group are not originally Caucacian despite their having appearances similar to those of Caucasians. A long time ago, they came from somewhere in Asia and then settled in Europe. The linguistic similarity among their languages betray this common origin. Thus, the differences observed in this type of disease and its symptoms between the above 2 population groups might be based on genetic differences.

However this Turkish article did not report any difference, although the Turks are also originally Asian. Furthermore, these days in South Korea, despite Koreans having an Asian root, colorectal cancer has been increasing rapidly, as has the consumption of dairy products. Therefore ethnic lineage cannot explain everything [13].

Intestinal galactose produced by lactase has a protective effect against colon cancer by binding lectins with inhibiting mucosal proliferation. Thus, lower amount of galactose in decreased activity of galatase leads to the pathogenetic process developing to cancer. One of the most common glycosylation abnormalities in colon cancer is the increased mucosal expression of the galactose$\beta-1,3-\mathrm{N}$-acetylgalactosamine, known as the Thomsen-Friedenreich blood-group antigen. This compound adversely affects the 
ability of intestinal galactose to bind to lectins, which are known to stimulate colon epithelial proliferation. This phenomenon must be investigated further if we are going to be able to determine whether or not it contributes to the initiation and/or development of cancer. Diverse studies, such as the one reported in this article, but with different ethnic characteristics, should be done to determine the factors that contribute to the development of colorectal cancer $[13,14]$.

\section{CONFLICT OF INTEREST}

No potential conflict of interest relevant to this article was reported.

\section{REFERENCES}

1. Suchy FJ, Brannon PM, Carpenter TO, Fernandez JR, Gilsanz V, Gould JB, et al. National Institutes of Health Consensus Development Conference: lactose intolerance and health. Ann Intern Med 2010;152:792-6.

2. Wang Y, Harvey CB, Hollox EJ, Phillips AD, Poulter M, Clay P, et al. The genetically programmed down-regulation of lactase in children. Gastroenterology 1998;114:1230-6.

3. Swallow DM. Genetics of lactase persistence and lactose intolerance. Annu Rev Genet 2003;37:197-219.

4. He T, Priebe MG, Harmsen HJ, Stellaard F, Sun X, Welling GW, et al. Colonic fermentation may play a role in lactose intolerance in humans. J Nutr 2006;136:58-63.
5. Misselwitz B, Pohl D, Frühauf H, Fried M, Vavricka SR, Fox M. Lactose malabsorption and intolerance: pathogenesis, diagnosis and treatment. United European Gastroenterol J 2013;1:151-9.

6. Amiri M, Diekmann L, von Köckritz-Blickwede M, Naim HY. The diverse forms of lactose intolerance and the putative linkage to several cancers. Nutrients 2015;7:7209-30.

7. Sanchez B, De Los Reyes-Gavilán CG, Margolles A, Gueimonde M. Probiotic fermented milks: present and future. Int J Dairy Technol 2009;62:472-83.

8. Kuokkanen M, Butzow R, Rasinperä H, Medrek K, Nilbert M, Malander S, et al. Lactase persistence and ovarian carcinoma risk in Finland, Poland and Sweden. Int J Cancer 2005;117:90-4.

9. Holt PR. New insights into calcium, dairy and colon cancer. World J Gastroenterol 2008;14:4429-33.

10. Ma RW, Chapman K. A systematic review of the effect of diet in prostate cancer prevention and treatment. J Hum Nutr Diet 2009; 22:187-99.

11. Vargas AJ, Thompson PA. Diet and nutrient factors in colorectal cancer risk. Nutr Clin Pract 2012;27:613-23.

12. Baena R, Salinas P. Diet and colorectal cancer. Maturitas 2015; 80:258-64.

13. Gencdal G, Salman E, Özütemiz Ö, Akarca US. Association of LCT-13910 C/T polymorphism and colorectal cancer. Ann Coloproctol 2017;33:169-72.

14. Campbell BJ, Finnie IA, Hounsell EF, Rhodes JM. Direct demonstration of increased expression of Thomsen-Friedenreich (TF) antigen in colonic adenocarcinoma and ulcerative colitis mucin and its concealment in normal mucin. J Clin Invest 1995;95:571-6. 